MARTA J. SKRODZKA

ANNA SZAFRANEK

MATEUSZ HUBERT ZIEMBLICKI

https://doi.org/10.33995/wu2021.2.4

\title{
Mediacja w sporach na rynkach finansowych na przykładzie Centrum Mediacji Sądu Polubownego przy Komisji Nadzoru Finansowego
}

Celem niniejszego artykułu jest zwięzłe przedstawienie istoty mediacji i specyfiki sporów występujących na rynkach finansowych. Wskazane omówienie posłużyć ma m.in. analizie postępowań mediacyjnych prowadzonych na rynkach finansowych, opartej na pilotażowych badaniach empirycznych (metodq studium przypadku], przeprowadzonych w Centrum Mediacji Sqdu Polubownego KNF, oraz określeniu roli wyspecjalizowanych centrów mediacji w rozwoju mediacji pozasqqdowej w Polsce. Autorzy stawiaja tezę, że wyspecjalizowane centra mediacyjne, zajmujace się prowadzeniem postępowań mediacyjnych wyłącznie w ściśle określonej kategorii spraw cywilnych i gospodarczych, wykazuja dużq efektywność, dlatego moga wspomóc postępowania sqdowe lub zastapić je w tym zakresie. W zwiqzku z tym wyspecjalizowane centra powinny być wspierane odpowiednimi regulacjami prawnymi, które pozwoliłyby na ich rozwój, stanowiqc alternatywę dla ogólnych centrów zajmujacych się prowadzeniem postępowań mediacyjnych we wszystkich możliwych kategoriach spraw nadajacych się do mediacji.

Słowa kluczowe: ADR, mediacja, postępowania polubowne, centrum mediacji, Komisja Nadzoru Finansowego.

\section{Wprowadzenie}

Zainteresowanie alternatywnymi metodami rozwiązywania sporów (ang.ADR - Alternative Dispute Resolution ], w tym zastosowaniem mediacji w zakresie rozwiązywania sporów sadowych z zakresu 
prawa cywilnego i gospodarczego stale rośnie ${ }^{1}$. Wydaje się, że przyczynami takiego stanu rzeczy są,

1. Analiza zebranych przez Ministerstwo Sprawiedliwości danych statystycznych odnoszących się do postępowań mediacyjnych w sprawach cywilnych i gospodarczych przeprowadzonych w sądach rejonowych w latach 2006-2020, wskazuje, że liczba spraw skierowanych do mediacji stopniowo rośnie. Wzrost liczby spraw kierowanych do mediacji przez sądy jest pierwszym sygnałem wzrostu zainteresowania tą metodą rozwiązywania sporów w środowisku sędziowskim. W odniesieniu do ogółu spraw cywilnych skierowanych do mediacji przez sądy rejonowe liczba tych spraw w 2006 r. wynosiła 395, w roku 2010 - 661, w roku 2015 - 1597, zaś w roku 2020 już 4751 sprawy (ponad 12-krotny wzrost na przestrzeni lat). Podobnie kształtowała się sytuacja ze sprawami gospodarczymi, gdzie w 2006 roku sądy rejonowe skierowały do mediacji 140 spraw, w 2010 roku - 656, w 2015 roku - 4138, zaś w roku 2020 - 3950 spraw (ponad 28-krotny wzrost na przestrzeni lat). Tendencję zwyżkową notują także sądy okręgowe, przy czym w roku 2006 saddy te skierowały 1053 sprawy cywilne do mediacji, w roku 2010 - 1535, w roku 2015 - 2550, zaś w roku 2020 4656 spraw (ponad 4-krotny wzrost na przestrzeni lat). Również w odniesieniu do spraw gospodarczych skierowanych do mediacji uwidacznia się wyraźny wzrost: od 116 w 2006 r., przez 192 w 2010 roku i 1606 w 2015 roku, po 2250 spraw w 2020 roku (ponad 19-krotny wzrost liczby spraw na przestrzeni lat). Jak podkreśla Ministerstwo Sprawiedliwości, pomimo rokrocznego wzrostu ogółu liczby spraw wpływających do sądów powszechnych w Polsce, stale zwiększa się również ogólny odsetek spraw kierowanych do mediacji w stosunku do wszystkich spraw wpływających do sądu, w których mediacja może znaleźć zastosowanie, co odzwierciedlają przytoczone powyżej dane. Odsetek tych spraw w roku 2020 pierwszy raz osiagnął wysoki poziom - 1,6\% i to pomimo nieznacznych wahnięć (w porównaniu z danymi chociażby z roku 2019), spowodowanych prawdopodobnie epidemią wirusa SARS-CoV2. Obok zwiększającej się liczby spraw kierowanych do mediacji w wymiarze sprawiedliwości stale wzrasta także liczba tych, w których strony wyrażaja zgodę na wzięcie udziału w postępowaniu mediacyjnym, oraz liczba ugód zawieranych w ramach tak prowadzonego postępowania. W odniesieniu do ogółu spraw cywilnych skierowanych do mediacji przez sądy rejonowe liczba tych, w których strony wzięły udział w postępowaniu mediacyjnym (do sądu wpłynął bowiem protokół z mediacji) w 2006 r. wynosiła 235 (co stanowi 59,5\% spraw, w których po wydaniu postanowienia przez sąd, przeprowadzono mediację), w roku 2010 - 368 (55,7\%), w roku 2015 - 1070 (67\% spraw, w których przeprowadzono mediację), zaś w roku 2020 już 3616 sprawy [76,1\%). To oznacza, że na przestrzeni lat liczba spraw cywilnych w sądach rejonowych, w których strony wyraziły zgodę na przeprowadzenie postępowania mediacyjnego, po skierowaniu z sądu wzrosła o 27,9\%. Podobnie kształtowała się sytuacja ze sprawami gospodarczymi: w 2006 roku, w ramach skierowanych przez sądy rejonowe wniosków przeprowadzono 71 postępowań mediacyjnych (czyli w 50,7\% spraw, w których sąd przekazał wniosek o przeprowadzenie mediacji), w 2010 roku - 274 (41,76\%), w 2015 roku - 1105 (26,7\%), zaś w roku 2020 - 2694 (68,2\%). Pomimo wahnięć (w 2015 roku liczba spraw w których przeprowadzono postępowanie mediacyjne w sporach gospodarczych w sadach rejonowych spadła] spowodowanych prawdopodobnie koniecznościa zmiany przepisów statuujących prowadzenie postępowania mediacyjnego, która zresztą (o czym będzie mowa w dalszej części artykułu) została przeprowadzona w 2016 r., na przestrzeni lat liczba spraw gospodarczych w sądach rejonowych, w których strony wyraziły zgodę na udział w postępowaniu mediacyjnym, po otrzymaniu sądowego postanowienia o skierowaniu sprawy do mediacji wzrosła o 34,5\%. Tendencję zwyżkową wykazuja także sądy okręgowe, przy czym w roku 2006 w ramach sporów skierowanych do mediacji przeprowadzono ją w 546 sprawach cywilnych (51,85\%), w roku 2010 - 1076 (70,1\%), w roku 2015 - 1992 [78,1\%), zaś w roku 2020 - w 4267 sprawach cywilnych [91,6\%!]. Powołane dane wskazuja, że aktualnie prawie we wszystkich sprawach cywilnych kierowanych do mediacji przez sądy okręgowe skonfliktowane strony biorą udział w postępowaniu mediacyjnym. Również w odniesieniu do spraw gospodarczych skierowanych do mediacji uwidacznia się wyraźne zwiększenie liczby przeprowadzonych mediacji: od 44 w 2006 r. (37,9\%), przez 101 w 2010 roku [52,6\%), 796 w 2015 roku (49,6\%), po 1807 mediacji w 2020 roku (80,3\%). Wzrost liczby spraw na przestrzeni lat, w których strony będące w sporze gospodarczym o wartości przedmiotu sporu ponad 75 000,00 zł, o 111,9\% - podobnie jak powołane wcześniej tendencje zwyżkowe wskazuja, że mediacja jako metoda rozwiązania sporu znajduje uznanie nie tylko wśród sędziów, ale również stron będących w sporze, którego rozstrzygnięciem miał zająć się wymiar sprawiedliwości. Taką tezę wzmacnia również analiza danych obrazująca liczbę ugód zawartych w postępowaniach mediacyjnych. Jak wskazuje Ministerstwo Sprawiedliwości, wskaźnik ugód zawieranych w sprawach cywilnych, który w roku 2020 ukształtował się na poziomie 32,13\%, wzrósł niemalże 5-krotnie tylko na przestrzeni lat 2013-2020. Powołane dane statystyczne dostępne są na stronie internetowej Ministerstwa Sprawiedliwości, https://isws.ms.gov.pl/pl/baza-statystyczna/opracowania-wieloletnie/ [dostęp: 4.05.2021]. 
poza innymi działaniami²: inicjatywa podjęta i realizowana w latach 2014-2015 przez Ministerstwo Gospodarki, polegająca na przeprowadzeniu projektu pilotażowego Centra Arbitrażu i Mediacji ${ }^{3}$, oraz działania Ministerstwa Sprawiedliwości, polegające na ustanowieniu w 2017 roku Centrów Arbitrażu i Mediacji w każdym województwie w Polsce 4 . W ramach wskazanych projektów powołano do działania jednolite Centra Arbitrażu i Mediacji w szesnastu wybranych miastach kraju. Ich zadaniem było (i w dalszym ciagu jest) propagowanie idei mediacji; przeszkolenie sędziów, prokuratorów i przyszłych oraz obecnych mediatorów w zakresie procedury mediacyjnej; jak również prowadzenie postępowań mediacyjnych, zarówno sądowych jak i pozasądowych, przede wszystkim w sporach gospodarczych. Powstałe jednostki wzmocniły inicjatywy podejmowane przez największe istniejące już centra mediacji, tworzone przez samorzady zawodowe i gospodarcze, jak chociażby: Centrum Mediacji przy Krajowej Radzie Radców Prawnych, Centrum Mediacji przy Naczelnej Radzie Adwokackiej, Centrum Mediacji przy Konfederacji Lewiatan czy Centrum Mediacji funkcjonujące przy Sądzie Arbitrażowym przy Krajowej Izbie Gospodarczej. Zdaniem autorów drugim czynnikiem mającym wpływ na wzrost liczby spraw kierowanych do mediacji przez sądy cywilne i gospodarcze była postulowana od dawna przez środowisko związane z idea mediacji ${ }^{5}$ nowelizacja przepisów aktów prawnych odnoszących się do postępowania mediacyjnego, w tym przepisów Kodeksu postępowania cywilnego ${ }^{6}$. Zmiany

2. Niektóre działania mające wpływ na popularyzację idei mediacji w Polsce, zostały wskazane i przeanalizowane przez Agrotec Polska Sp. z 0.o., w Raporcie końcowym z badania Diagnoza stanu stosowania mediacji oraz przyczyn zbyt niskiej w stosunku do oczekiwanej popularności mediacji, który powstał na zlecenie Wydziału ds. Pokrzywdzonych Przestępstwem i Promocji Mediacji Departamentu Współpracy Międzynarodowej i Praw Człowieka w Ministerstwie Sprawiedliwości w ramach projektu Propagowanie alternatywnych metod rozwiqzywania sporów wdrażanego w ramach Programu Operacyjnego Budowanie potencjału instytucjonalnego i współpraca w obszarze wymiaru sprawiedliwości / Poprawa skuteczności wymiaru sprawiedliwości współfinansowanego ze środków Norweskiego Mechanizmu Finansowego 2009-2014. Raport końcowy dostępny jest na stronie internetowej poświęconej mediacji: http://mediacja.gov.pl/Badania-analizy-i-statystyki-.html [dostęp: 10.11.2020].

3. Więcej informacji nt. projektu, jego założeń i realizacji jest dostępnych na stronie internetowej: - Centra Arbitrażu i Mediacji: https://www.cammediacje.pl/assets/files/raport-cam-final.pdf [dostęp: 10.11.2020].

4. Powołanie 16 Centrów Arbitrażu i Mediacji w Polsce zostało przeprowadzone w ramach dwóch projektów wyłonionych w ramach konkursów nr POWR.02.17.00-IP.04-00-001/17 i POWR.02.17.00-IP.04-00-010/17, realizowanych przez Ministerstwo Sprawiedliwości, a dofinansowanych ze środków Unii Europejskiej w ramach Programu Operacyjnego Wiedza Edukacja Rozwój 2014-2020.

5. Zob. m.in. działania (oraz toczącą się w związku z tym dyskusję) Społecznej Rady ds. ADR funkcjonującej przy Ministrze Sprawiedliwości, która opracowała w 2009 r. roboczy projekt ustawy o mediatorach i zasadach prowadzenia mediacji w sprawach skierowanych przez organa procesowe (informacja ta pochodzi ze strony Wydawnictwa Wolters Kluwer S.A.: http://www.mediacje.lex.pl/czytaj/-/artykul/spoleczna-rada-o-projekcie-ustawy-o-mediatorach oraz http://www.lex.pl/czytaj/-/artykul/ms-pracuje-nad-nowymi-przepisami-o-mediacji [dostęp: 24.08.2021]. Robocza wersja projektu ustawy jest zaś dostępna na stronie internetowej Mobbing akademicki - mediator akademicki: http://nfamob.wordpress.com/2009/11/05/projekt-roboczy-ustawy-o-mediatorach-i-zasadach-prowadzenia-mediacji/ [dostęp: 24.08.2021]]). W 2012 r. Społeczna Rada ds. ADR przygotowała dokument pt.: Założenia ogólne propozycji działań zmierzajacych do pełniejszego wykorzystania potencjału mediacji jako skutecznej metody rozwiqzywania sporów i konfliktów, w którym wyraźnie wskazano na potrzebę nie tylko doprecyzowania przepisów regulujących instytucję mediacji, ale także ich ujednolicenia (dokument dostępny na stronie internetowej Ministerstwa Sprawiedliwości: http://ms.gov.pl/ $\mathrm{pl} / \mathrm{dzialalnosc/mediacje/spoleczna-rada-ds-alternatywnych-metod-rozwiazywania-konfliktow-i-sporow/}$ dokumenty-deklaracje/ [dostęp: 10.11.2020].

6. Ustawa z 10 września 2015 r. o zmianie niektórych ustaw w związku ze wspieraniem polubownych metod rozwiązywania sporów (Dz. U. 2015, poz. 1595). 
wprowadzone tylko do k.p.c. polegały na wzmocnieniu: zasady ugodowego rozwiązania sporu poprzez obowiązek nakłaniania stron do mediacji (art. 10 k.p.c.), zasady poufności mediacji (art. $183^{4}$ $\S 2$ k.p.c.)oraz obowiązku informowania przez sąd o możliwości skierowania sprawy do mediacji, szczególnie na wstępnym etapie postępowania (art. $183^{8}$ k.p.c.). Ponadto nowelizacja przepisów k.p.c. pozwoliła na wprowadzenie: zmiany wynagrodzenia mediatora za mediację ze skierowania sądu (art. $98^{1} \S 4$ k.p.c.), przerwania biegu przedawnienia roszczenia poprzez udział w postępowaniu mediacyjnym (art. $183^{6} \S 3$ k.p.c.), mediacji w postępowaniach upominawczych i nakazowych (art. $183^{8} \S 3$ k.p.c.), obowiązku informowania już w pozwie czy strony podjęły próbę mediacji lub innego pozasądowego sposobu rozwiązania sporu przed skierowaniem sprawy do sądu (art. 187 § 1 pkt 3 k.p.c.); jak również wpłynęła na uporządkowanie kwestii proceduralnych dotyczacych mediacji (art. $183^{9}$ k.p.c.). Pomimo że wprowadzone zmiany nie odzwierciedliły wszystkich oczekiwań osób i podmiotów zainteresowanych wskazana problematyka, były pierwszym, słusznym krokiem, który w przekonaniu autorów przyczynił się do efektywnego wykorzystania instytucji mediacji w sporach cywilnych i gospodarczych.

0 ile z danych statystycznych gromadzonych przez Ministerstwo Sprawiedliwości dokładnie wynika liczba spraw cywilnych i gospodarczych kierowanych przez sądy powszechne do postę-

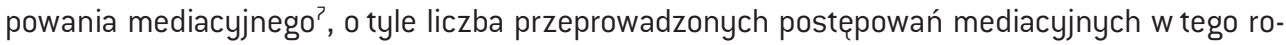
dzaju sporach pozasądowych nie jest znana. Wynika to m.in. z faktu, że obowiązujące przepisy prawa zasadniczo nie reguluja konieczności prowadzenia statystyk pozasądowych postępowań mediacyjnych oraz nie nakładaja obowiązku sprawozdawczości w tym zakresie na organizacje i instytucje prowadzące tego typu postępowania. Częściowe wsparcie - przynajmniej w odniesieniu do niektórych sporów cywilnych (w zakresie oszacowania liczby prowadzonych mediacji pozasądowych oraz skali problemu - liczby sporów) może stanowić ustawa o pozasądowym rozwiązywaniu sporów konsumenckich ${ }^{8}$, która nakłada obowiązek sprawozdawczości na objęte jej zakresem podmioty, jak również prowadzenie określonego jej przepisami Rejestru podmiotów uprawnionych do prowadzenia postępowań w ramach pozasądowego rozwiązywania sporów ${ }^{9}$. Przedmiotowy Rejestr, który w chwili obecnej ${ }^{10}$ zawiera 12 uprawnionych podmiotów, obejmuje m. in. informacje nt. stron internetowych poszczególnych podmiotów, na których można zapoznać się z rocznymi raportami poświęconymi ich działalności, w tym odnoszącymi się do postępowań prowadzonych w ramach pozasądowego rozwiązywania sporów. Kwestia ta wydaje się być warta dalszego zbadania (i stanie się przedmiotem kolejnych analiz autorów), po pierwsze w celu sprawdzenia, jaki jest wpływ przepisów ustawy o pozasądowym rozwiązywaniu sporów konsumenckich na rozwój postępowań prowadzonych w ramach pozasądowego rozwiązywania sporów konsumenckich w Polsce, powstawanie wyspecjalizowanych centrów mediacji oraz ich efektywność w zakresie prowadzonych postępowań. Po drugie, przedmiotowe dane można poddać kolejnej analizie, aby odpowiedzieć na pytania o potrzebę i kierunek dalszych ewentualnych regulacji

7. Zob. przypis 4.

8. Ustawa z dnia 23 września 2016 r. o pozasądowym rozwiązywaniu sporów konsumenckich (Dz. U. 2016, poz. 1823, z późn. zm.), dalej jako u.p.r.s.k. Zgodnie z przepisem art. 2 pkt 3) ustawy sporem konsumenckim jest spór pomiędzy konsumentem a przedsiębiorca, wynikajacy z zawartej między nimi umowy (w sytuacji gdy sprzedawca, usługodawca lub gwarant odmówią uznania reklamacji konsumenta, który jest pewny swojej racji].

9. Rejestr dostępny pod adresem: http://polubowne.uokik.gov.pl/rejestr,5,pl.html [dostęp: 10.11.2020].

10. Stan na: 30 czerwca $2021 \mathrm{r}$. 
prawnych majacych zastosowanie do innych wyspecjalizowanych instytucji i organizacji, które zajmuja się prowadzeniem pozasądowych postępowań mediacyjnych.

Odnosząc się do problematyki niniejszego opracowania, należy wskazać, że poza sądami powszechnymi przykładem instytucji specjalizującej się w rozwiązywaniu określonych sporów (konsumenckich], i to w trybie pozasądowym, istniejącej przed wprowadzeniem przepisów u.p.r.s.k, jest Komisja Nadzoru Finansowego (dalej: KNF), która 31 marca 2008 roku powołała Centrum Mediacji Sądu Polubownego ${ }^{11}$. Z informacji dostępnych w internecie wynika, że liczba spraw, którymi zajmowało się Centrum, z roku na rok znacząco wzrasta. Jak podaje „Rzeczpospolita”, w 2015 roku do Centrum Mediacji Sądu Polubownego KNF skierowano łącznie 511 wniosków o postępowanie mediacyjne, z czego w 135 sprawach strony wyraziły zgodę na jego przeprowadzenie ${ }^{12}$. Dla porównania: w 2014 r. wniosków o mediację było o 1/3 mniej, bo 347 ${ }^{13}$. Jak wynika ze sprawozdań z działalności Komisji Nadzoru Finansowego za okres 2016-201914, w kolejnych latach liczba wniosków o przeprowadzenie mediacji wynosiła kolejno: 1775 w roku 2016 (z czego w 611 sprawach strony wyraziły zgodę na przeprowadzenie mediacji, co oznacza prowadzenie jej w 34,4\% wniosków), 2941 w roku 2017 (w ramach których w 1016 sprawach strony wyraziły zgodę na przeprowadzenie postępowania mediacyjnego - co stanowi 40,8\% wniosków), 2314 w roku 2018 (z czego zgody na przeprowadzenie mediacji udzielono zgody w 1040 sprawach, a więc w 44,9\% złożonych w tym roku wniosków), 2724 w roku 2019 (z których w 1569 sprawach strony zgodziły się na mediację, co oznacza wykorzystanie tej procedury w 57,6\% wniosków złożonych w tej sprawie) oraz 2187 w roku 2020 (w ramach których w 1006 sprawach, a więc w 46\% złożonych wniosków, strony wyraziły zgodę na wszczęcie postępowania mediacyjnego]. Analiza powołanych danych prowadzi do konkluzji, że Centrum Mediacji Sądu Polubownego KNF, pomimo odnotowania jednorocznego spadku liczby wniosków w 2020 roku, w których strony wyraziły zgodę na wzięcie udziału w postępowaniu mediacyjnym ( prawdopodobnie wywołanego epidemią wirusa SARS-CoV2, ze względu na konieczność czasowego zawieszenia działalności Centrum, co znalazło swoje odzwierciedlenie również w przedstawianych wcześniej danych statystycznych sądów powszechnych) wykazuje

11. Komisja Nadzoru Finansowego została zobowiązana do powołania Sądu Polubownego na podstawie art. 18 ustawy z dnia 21 lipca 2006 r. o nadzorze nad rynkiem finansowym (Dz. U. nr 157, poz. 1119 z późn. zm.) zob. m.in. https://www.knf.gov.pl/knf/pl/komponenty/img/SP\%20przy\%20KNF\%20-\%200\%20mediacji_6745?. pdf [dostęp: 13.11.2020]. Centrum Mediacji Sądu Polubownego KNF działa w oparciu o Uchwałę nr 106/2019 Komisji Nadzoru Finansowego z dnia 26 marca 2019 r. w sprawie „Regulaminu Sadu Polubownego przy Komisji Nadzoru Finansowego" (Dz. Urz. KNF2019.13 z dnia 2019.04.04).

12. Zob. np.: KNF nagradza ubezpieczycieli za mediacje, „Rzeczpospolita” 31.03.2016, http://www.rp.pl/ Ubezpieczenia/303319899-KNF-nagradza-ubezpieczycieli-za-mediacje.html\#ap-1 [dostęp: 13.11.2020].

13. Ibidem.

14. Sprawozdanie z działalności Komisji Nadzoru Finansowego w roku 2016 dostępne pod adresem: https://www. knf.gov.pl/knf/pl/komponenty/img/1_OST_PRZYJETY_28_03_na\%20KNF_28_03_Sprawozdanie_2016.pdf [dostęp: 10.12.2020]. Sprawozdanie z działalności Urzędu Komisji Nadzoru Finansowego oraz Komisji Nadzoru Finansowego w roku 2018 dostępne pod adresem: https://www.knf.gov.pl/knf/pl/komponenty/img/Sprawozdanie\%20z\%20działalności\%20UKNF\%20oraz\%20KNF\%20w\%202018\%20roku_66979.pdf [dostęp: 10.12.2020]. Sprawozdanie z działalności Urzędu Komisji Nadzoru Finansowego oraz Komisji Nadzoru Finansowego w roku 2019 dostępne pod adresem: https://www.knf.gov.pl/knf/pl/komponenty/img/Sprawozdanie\%202019.pdf [dostęp: 10.12.2020]. Sprawozdanie z działalności Urzędu Komisji Nadzoru Finansowego oraz Komisji Nadzoru Finansowego w roku 2020 dostępne pod adresem: https://www.knf.gov.pl/knf/pl/komponenty/img/ Sprawozdanie_z_dzialalnosci_UKNF_oraz_KNF_w_2020_roku_73572.pdf [dostęp: 30.06.2021]. 
zasadniczo tendencję zwyżkową. Świadczy to zatem o popularności postępowania mediacyjnego wśród stron przedmiotowego postępowania w Centrum. Ponadto mediatorzy Centrum Mediacji Sąu Polubownego przy KNF niejednokrotnie pomogli stronom rozwiązać spór i zakończyć go jeszcze przed wszczęciem postępowania mediacyjnego (poprzez doprowadzenie do zawarcia ugody lub złożenia propozycji zawarcia ugody], co również znajduje odzwierciedlenie w przywołanych statystykach ${ }^{15}$. Prowadzone postępowania mediacyjne cieszą się również wysoką, bo ok. 80\% skutecznością, przez którą rozumiane jest zawarcie ugody przez strony ${ }^{16}$.

Ogólne porównanie polegające na zestawieniu odsetka liczby przeprowadzonych postępowań mediacyjnych z liczbą wniosków o przeprowadzenie mediacji w Centrum Mediacji Sądu Polubownego KNF w ostatnim roku - 2020 (46\%) oraz odsetka liczby przeprowadzonych mediacji w sadach powszechnych z liczbą spraw skierowanych do mediacji w tym samym okresie (ok. 25,6\% ${ }^{17}$ ); jak również porównanie skuteczności prowadzonych mediacji (ok. 80\% do ok. 32,1\% ${ }^{18}$ ) prowadzi do wstępnego wniosku, że Centrum Mediacji Sądu Polubownego KNF jest skuteczną i chętnie wykorzystywaną instytucją ułatwiającą rozwiązywanie sporów konsumenckich na rynkach finansowych. Istotne zatem jest dokładne zbadanie i przeanalizowanie przyczyn takiego stanu rzeczy.

Celem niniejszego artykułu jest zwięzłe przedstawienie istoty mediacji i specyfiki sporów występujacych na rynkach finansowych. Wskazane omówienie posłużyć ma m.in. analizie postępowań mediacyjnych prowadzonych na rynkach finansowych, opartej na pilotażowych badaniach empirycznych (metodą studium przypadku) przeprowadzonych w Centrum Mediacji Sadu Polubownego KNF, oraz określeniu roli wyspecjalizowanych centrów mediacji w rozwoju mediacji pozasądowej w Polsce. Autorzy stawiają bowiem tezę, że wyspecjalizowane centra mediacyjne zajmujące się prowadzeniem postępowań mediacyjnych wyłącznie w ściśle określonej kategorii spraw cywilnych i gospodarczych wykazują dużą efektywność, dlatego mogą wspomóc postępowania sądowe lub zastapić je w tym zakresie. W związku z tym wyspecjalizowane centra powinny być wspierane odpowiednimi regulacjami prawnymi, które pozwoliłyby na ich rozwój, stanowiąc alternatywę dla ogólnych centrów zajmujących się prowadzeniem postępowań mediacyjnych we wszystkich możliwych kategoriach spraw nadających się do mediacji.

\section{Istota mediacji}

Mediacja, jako jedna z tzw. alternatywnych (m.in. w stosunku do postępowania sądowego) metod rozwiązywania sporów, nie jest definiowana jednolicie ani w prawodawstwie międzynarodowym, ani w systemach prawnych poszczególnych państw ${ }^{19}$. Jak zauważa Don Peters, mediację nale-

15. Ibidem.

16. Por. m.in. informacje zawarte w powoływanych sprawozdaniach (zob. przypis 16) oraz w informacjach na stronie: https://www.knf.gov.pl/knf/pl/komponenty/img/SP\%20przy\%20KNF\%20-\%200\%20mediacji_6745?.pdf [dostęp: 10.12.2020].

17. Por. dane z przypisu 4.

18. Ibidem.

19. S. Pieckowski, Mediacja gospodarcza, Difin, Warszawa 2015, s. 27. Należy jednak podkreślić, że w Dyrektywie Parlamentu Europejskiego i Rady 2008/52/WE z 21 maja 2008 r. w sprawie niektórych aspektów mediacji w sprawach cywilnych i handlowych (Dz. U. UE L 136/3 z 24.05.2008), której transpozycja do polskiego porządku prawnego nastapiła ustawą z dnia 16 września 2011 r. o zmianie ustawy - Kodeks postępowania cywilnego oraz 
ży rozumieć jako „wspomagane negocjacje, które to stanowią najbardziej powszechny sposób budowania relacji oraz rozwiązywania sporów [...]”20. Zdaniem Allana J. Stitta, mediacja jest „niczym więcej niż wspomaganymi negocjacjami, a najlepszymi mediatorami są eksperci w procesie negocjacji, którzy pomagaja stronom przezwyciężyć przeszkody w negocjacjach [...]"21. Warto jednak zaznaczyć, że w polskim piśmiennictwie wyraźnie akcentuje się różnice pomiędzy mediacją a negocjacjami, co zdaje się stanowić o pewnej odrębności rozumienia tego pojęcia względem literatury anglojęzycznej ${ }^{22}$. Mediacja (łac. mediator - pośrednik, mediare - pośredniczyć, medius - bezstronny, środkowy ${ }^{23}$ określana bywa jako rodzaj rozwiązywania sporów, który opiera się na wyspecjalizowanej, niewładczej ingerencji bezstronnej oraz neutralnej wobec stron i ich konfliktu osoby trzeciej (mediatora). Zadaniem mediatora jest: 1) doprowadzenie do zawarcia porozumienia przez strony, które to porozumienie będzie następnie przez nie wzajemnie akceptowane przy jednoczesnym uwzględnieniu interesów oraz potrzeb obu stron, a także 2) pomoc w odbudowie relacji i postaw współpracy między stronami sporu ${ }^{24}$.

Charakterystycznymi, uniwersalnymi cechami mediacji, które oddajajej istotę, są: dobrowolność, akceptowalność, bezstronność, neutralność oraz poufność. Dobrowolność oznacza brak przymusu stron do rozpoczęcia mediacji, udziału w niej oraz osiągnięcia porozumienia, a także możliwość wycofania się z mediacji na każdym jej etapie. Przejawami dobrowolności są również możliwość wyboru lub zmiany osoby mediatora, znaczny wpływ stron na kształt postępowania mediacyjnego, w tym jego reguł, a także treści ewentualnej ugody ${ }^{25}$. W sposób nierozerwalny z dobrowolnością wiąże się zaakceptowanie przez strony osoby mediatora, jak również wypracowanego (przy udziale mediatora] sposobu rozwiązania sporu ${ }^{26}$. Bezstronność dotyczy natomiast osoby mediatora, którego

niektórych innych ustaw (Dz. U. 2011, nr 233, poz. 1381), w art. 3 lit. a i b znajdują się definicje mediacji oraz mediatora. Zgodnie z treścią powołanych przepisów mediacja oznacza zorganizowane postępowanie o dobrowolnym charakterze, bez względu na jego nazwę lub określenie, w którym przynajmniej dwie strony sporu próbują same osiagnać porozumienie w celu rozwiązania ich sporu, korzystając z pomocy mediatora. Postępowanie takie może zostać zainicjowane przez strony albo może je zaproponować lub zarządzić sąd lub nakazać prawo państwa członkowskiego. Termin ten obejmuje mediację prowadzoną przez sędziego, który nie jest odpowiedzialny za jakiekolwiek postępowanie sądowe dotyczące rzeczonego sporu. Nie obejmuje on jednak prób podejmowanych przez sąd lub sędziego rozstrzygającego spór w toku postępowania sądowego dotyczącego rzeczonego sporu. Mediatorem jest natomiast osoba trzecia, do której zwrócono się, aby przeprowadziła mediację w sposób skuteczny, bezstronny i kompetentny, bez względu na jej nazwę lub zawód wykonywany w danym państwie członkowskim oraz sposób jej wyznaczenia lub formę, w której zwrócono się do niej o przeprowadzenie mediacji.

20. D. Peters, An introduction to mediation theory and skills, University of Florida, Gainesville FL 2006, s. 1.

21. A.J. Stitt, Mediating commercial disputes, Canada Law Book Inc., Aurora 2003, s. 33.

22. Różnica między mediacją a negocjacjami polega na tym, że w przypadku mediacji strony proszą o pomoc bezstronnego mediatora, który w pewien sposób „zarządza” ich konfliktem, szukając wraz z nimi możliwości jego rozwiązania oraz zawarcia ugody; w przypadku negocjacji natomiast, strony same rozwiązują konflikt poprzez wzajemne negocjacje. Por. M. Malczyk, [w:] Kodeks postępowania cywilnego. Tom I. Komentarz. Art. 1-729, [red.] A. Góra-Błaszczykowska, CH Beck, Warszawa 2016, s. 591 oraz E. Stefańska, [w:] Kodeks postępowania cywilnego. Komentarz. Tom I. Art. 1-50538, [red.] M. Manowska, Wolters Kluwer, Warszawa 2015, s. 512.

23. Tak: A. Kalisz, A. Zienkiewicz, Mediacja sqdowa i pozasqdowa. Zarys wykładu, Wolters Kluwer, Warszawa 2014, s. 42, za:W. Kopaliński, Słownik wyrazów obcych i zwrotów obcojęzycznych z almanachem, PWN, Warszawa 2000, s. 321.

24. A. Kalisz, A. Zienkiewicz, op. cit., s. 42.

25. Ibidem, s. 69.

26. P. Nowak, B. Kornacka, Mediacja i inne polubowne formy rozwiqzywania sporów na rynku finansowym, KNF, Warszawa 2016, s. 8. 
głównym zadaniem jest pomoc w wypracowaniu satysfakcjonującego obie strony rozwiązania, bez faworyzowania którejkolwiek z nich, przy zachowaniu maksymalnego obiektywizmu. Neutralność, podobnie jak bezstronność, odnosi się do osoby mediatora i obejmuje niezajmowanie stanowiska wobec przedmiotu sporu. Mediacje cechuje także poufność, która polega na tym, że zarówno geneza konfliktu, jak również wszystkie informacje i ustalania, wynikające z procesu mediacji, objęte są tajemnica. Jak słusznie zauważa Sylwester Pieckowski, oddając tym samym istotę mediacji: „Mediacja jest emanacją społeczeństwa obywatelskiego, drogą rozwiązywania sporów i konfliktów społecznych na drodze dialogu i porozumienia. Jest realizacją wolności jednostki w kreowaniu jej relacji z drugim człowiekiem, bez uciekania się do pośrednictwa i nakazu państwa. W tym sensie mediacja jest lepsza postacią wymiaru sprawiedliwości i rozwiązywania sporów [...]"2?.

Podstawowymi rodzajami (zwanymi również typami lub modelami) mediacji wyróżnianymi w teorii ${ }^{28}$ są wyodrębniane ze względu na kryterium: 1) celu mediacji: mediacja rozwiązująca spór (oparta na interesach stron i ich analizie, zmierzająca do rozwiązania konfliktu) oraz mediacja transformatywna (zmierzająca do zmiany charakteru relacji wynikajacych z konfliktu), 2) dobrowolności: mediacja dobrowolna (zależna tylko od woli stron) i mediacja obligatoryjna (zależna od decyzji sądu), 3) roli i funkcji mediatora: mediacja facylitatywna (mediator organizuje i prowadzi mediacje, ograniczając się jedynie do ułatwiania kontaktu stron i poszukiwania rozwiązania konfliktu), a także mediacja ewaluatywna (mediator oprócz organizacji i prowadzenia mediacji aktywnie - wraz ze stronami - poszukuje rozwiązania konfliktu).

Poza wspomnianymi wyżej rodzajami mediacji, na szczególne podkreślenie - z uwagi na wymiar praktyczny - zasługuje podział mediacji ze względu na kryterium podstawy jej prowadzenia. Zgodnie z nim wyróżnić należy mediację umowna, prowadzoną w płaszczyźnie prywatnej (zwaną także kontraktową, bądź pozasądowa)], oraz mediację sądowa, prowadzoną w ramach wymiaru sprawiedliwości ${ }^{29}$. W przypadku mediacji umownej strony składają zgodne oświadczenie woli o poddaniu mediacji określonego sporu lub stosunku prawnego, z którego spór już wyniknął lub może wynikną́ w przyszłości ${ }^{30}$. Podstawowe elementy umowy o mediację zostały określone w art. $183^{1}$ $\S 3$ kodeksu postępowania cywilnego ${ }^{31}$. Zgodnie z treścia przepisu w umowie o mediację strony określaja w szczególności: przedmiot mediacji, osobę mediatora albo sposób jego wyboru. W praktyce, ze względu na cechującą mediację dobrowolność oraz zasadę swobody umów określona przez ustawodawcę w art. $353^{1}$ Kodeksu cywilnego ${ }^{32}$, strony w umowie o mediację (lub odpowiednio w klauzuli mediacyjnej, będącej elementem umowy materialnoprawnej] wskazać mogą m.in.: czas i miejsce mediacji, osobę mediatora, a także stworzyć szczegółowy regulamin mediacji, w oparciu o który mediacja będzie prowadzona. Mediacja sądowa polega natomiast na przysługującej sądowi

27. S. Pieckowski, op. cit., s. ?.

28. Por. S. Pieckowski, op. cit., 28, za: E. Gmurzyńska, [w:] Mediacje. Teoria i praktyka, [red.] E. Gmurzyńska, R. Morek, Wolters Kluwer, Warszawa 2009, s. 110-124 oraz E. Gmurzyńska, [w:] Mediacja, [red.] L. Mazowiecka, Wolters Kluwer, Warszawa 2009, s. 303-31?.

29. E. Gmurzyńska, [w:] Mediacje. Teoria ..., s. 122.

30. P. Nowak, B. Kornacka, op. cit., s. 9.

31. Ustawa z dnia 17 listopada 1964 r. - Kodeks postępowania cywilnego (tekst. jedn. Dz. U. 2020, poz. 1575 z późn. zm.) dalej jako: k.p.c.

32. Ustawa z dnia 23 kwietnia 1964 r. - Kodeks cywilny (tekst jedn. Dz. U. 2020, poz. 1740 z późn. zm.), dalej: k.c. 
możliwości skierowania stron do mediacji na każdym etapie postępowania (art. $183^{8} \S 1$ k.p.c. ${ }^{33}$ ). Postanowienie o skierowaniu stron do mediacji może być wydane na posiedzeniu niejawnym. Co istotne, mediacji sądowej nie prowadzi się, jeżeli strona w terminie tygodnia od dnia ogłoszenia lub doręczenia jej postanowienia o skierowaniu do mediacji nie wyraziła na nią zgody (art. $183^{8} \S 2$ k.p.c.). Przewodniczący może wezwać strony do udziału w spotkaniu informacyjnym (spotkanie to może poprowadzić sędzia, referendarz sądowy, urzędnik sądowy, asystent sędziego czy stały mediator), dotyczącym polubownych metod rozwiązywania sporów, w szczególności mediacji (art. $183^{8}$ $\S 4$ k.p.c.). Przed pierwszym posiedzeniem wyznaczonym na rozprawę przewodniczący dokonuje oceny, czy skierować strony do mediacji. W tym celu, jeżeli zachodzi potrzeba wysłuchania stron, może on wezwać je do osobistego stawiennictwa na posiedzeniu niejawnym (art. $183^{8} \S 5$ k.p.c.)

Poza różnicą wynikająca z podstawy prawnej, w oparciu o która prowadzi się postępowania mediacyjne w ramach mediacji umownej i sadowej, dodatkowo różnicuje je także m.in. osoba mediatora oraz czas trwania mediacji. W przypadku mediacji umownej zasadniczo mediator jest wybierany przez strony sporu (jak wskazano wyżej, wyboru tego dokonać moga nawet przed powstaniem sporu], mające przy tym właściwie nieograniczoną możliwość, co zwiększa szanse na wybór osoby, która spełni ich oczekiwania ${ }^{34}$. Strony mogą przy tym korzystać z usług mediatorów znajdujących się na listach stałych mediatorów sądowych, ale nie jest to warunek konieczny. Mogą bowiem korzystać z usług mediatorów spoza ww. list, m.in. kontaktując się w tym celu z wyspecjalizowanymi centrami, ośrodkami mediacji lub bezpośrednio z wybranym mediatorem. Możliwość wyboru mediatora (lub wyspecjalizowanego w danej dziedzinie ośrodka mediacyjnego) zwiększa szanse stron na wybór osoby doświadczonej, mającej ekspercką wiedzę w danej dziedzinie. W przypadku mediacji sądowej, jeżeli strony nie dokonały wyboru mediatora, sąd kierujący je do mediacji wyznacza mediatora mającego odpowiednią wiedzę i umiejętności w zakresie prowadzenia mediacji w sprawach danego rodzaju, biorąc pod uwagę w pierwszej kolejności stałych mediatorów (art. $183^{9} \S 1$ k.p.c.). Mediator ma prawo do zapoznania się z aktami sprawy, chyba że strona w terminie tygodnia od dnia ogłoszenia lub doręczenia postanowienia kierującego strony do mediacji nie wyrazi na to zgody (art. $183^{9}$ $\S 2$ k.p.c.). W przypadku mediacji umownej - jak zostało to zasygnalizowane wyżej - ze względu na dobrowolność mediacji oraz zasadę swobody umów, wynikającą z art. $353^{1}$ k.c., czas trwania mediacji może zostać określony według uznania stron w umowie o mediację. Zgodnie z art. $183^{10} \S 1$ k.p.c. sąd, kierujac strony do mediacji, wyznacza czas jej trwania na okres do trzech miesięcy (jednak na zgodny wniosek stron lub z innych ważnych przyczyn, termin na przeprowadzenie mediacji może zostać przedłużony, jeżeli sprzyjać będzie ugodowemu rozwiązaniu sporu).

Jak wynika z informacji dostępnych na stronach internetowych KNF, postępowanie mediacyjne prowadzone w Centrum Mediacji Sądu Polubownego KNF charakteryzuje się wszystkimi wskazanymi wcześniej cechami, tj. dobrowolnością, akceptowalnością, bezstronnością, neutralnością oraz poufnościa, i jest prowadzone w oparciu o zasady przewidziane przepisami k.p.c. ${ }^{35}$. Na marginesie

33. Zgodnie z art. $183^{8} \S 3$ k.p.c. przepisu $\S 1$ nie stosuje się w sprawach rozpoznawanych w postępowaniach upominawczym oraz nakazowym, chyba że doszło do skutecznego wniesienia zarzutów.

34. R. Morek, [w:] Mediacje. Teoria ..., s. 185.

35. Por. materiały informacyjne nt. mediacji dostępne na stronie Centrum Mediacji Sądu Polubownego KNF: https:// www.knf.gov.pl/knf/pl/komponenty/img/0_mediacji_slajdy\%202019_65959.pdf [dostęp: 10.12.2020] oraz przepisy § 16-19 Uchwały nr 106/2019 Komisji Nadzoru Finansowego z dnia 26 marca 2019 r. w sprawie „Regulaminu Sądu Polubownego przy Komisji Nadzoru Finansowego” (Dz. Urz. KNF2019.13 z dnia 4 kwietnia 2019 r.) odnoszące się do postępowania mediacyjnego. 
warto zaznaczyć, że w związku z wejściem w życie przepisów u.p.r.s.k. Centrum może prowadzić także postępowania w trybie określonym przepisami przedmiotowej ustawy charakteryzujace się nieco odmiennymi zasadami ${ }^{36}$. Postępowanie mediacyjne prowadzone w Centrum Mediacji Sadu Polubownego KNF jest również odpłatna (koszt postępowania mediacyjnego to 50 zł) mediacja pozasądową (prowadzoną w oparciu o złożone przez strony zgodne oświadczenie woli o poddaniu mediacji określonego sporu]. To, co wyróżnia przedmiotowa procedurę na tle typowych postępowań mediacyjnych, to możliwość rozwiązania w jego ramach sporu występującego na rynku finansowym oraz fakt jego prowadzenia przez mediatora (lub zespół mediatorów) posiadającego specjalistyczną wiedzę z zakresu sporów na rynku finansowym ${ }^{37}$. Warto w związku z tym odpowiedzieć na pytanie, czym są spory występujące na rynku finansowym.

\section{Spory na rynku finansowym}

Rynek finansowy tradycyjnie definiowany jest w ekonomii w szerokim i wąskim ujęciu. W znaczeniu szerokim w struktury rynku finansowego włączane są zarówno działania, które dotycza pieniędzy, ich przepływu, operacji rozliczeniowych, jak również działania gospodarcze, oparte są na obrocie pieniężnym ${ }^{38}$. W węższym rozumieniu rynek finansowy obejmuje natomiast decyzje związane wyłącznie ze środkami pieniężnymi, których celem jest ochrona wartości pieniędzy posiadanych lub jej wzrost w przyszłości ${ }^{39}$. Zdaniem Jacka Sochy rynkiem finansowym są wszelkie operacje związane z obrotem środkami pieniężnymi ${ }^{40}$. Wiesław Dębski pod pojęciem rynku finansowego rozumie ogół transakcji instrumentami finansowymi będącymi przedmiotem udzielania kredytów krótko-, średnio- i długoterminowych ${ }^{41}$. W ujęciu nauki finansów na rynek finansowy składają się: rynek pieniężny, rynek kredytowy, rynek walutowy, rynek instrumentów pochodnych oraz rynek kapitałowy ${ }^{42}$.

Do podmiotów rynku finansowego zaliczyć należy m.in.: podmioty sektora bankowego, sektora emerytalnego, sektora ubezpieczeniowego, sektora rynku kapitałowego, instytucje płatnicze, biura usług płatniczych, instytucje pieniądza elektronicznego, oddziały zagranicznych instytucji pieniądza elektronicznego, agencje ratingowe, instytucje kredytowe, zakłady ubezpieczeń,

36. Zgodnie z przepisem art. 3 u.p.r.s.k. postępowanie w sprawie pozasądowego rozwiązywania sporów konsumenckich polega na: umożliwieniu zbliżenia stanowisk stron w celu rozwiązania sporu przez jego strony; przedstawieniu stronom propozycji rozwiązania sporu; rozstrzygnięciu sporu i narzuceniu stronom jego rozwiązania. Odmiennie zatem od typowego postępowania mediacyjnego charakteryzuje się ono możliwością przedstawienia przez mediatora propozycji rozwiązania sporu stronom.

37. Por. przepisy $\S 8$ Uchwały nr 106/2019 Komisji Nadzoru Finansowego z dnia 26 marca 2019 r. w sprawie „Regulaminu Sądu Polubownego przy Komisji Nadzoru Finansowego” (Dz. Urz. KNF2019.13 z dnia 4 kwietnia 2019) odnoszące się do osoby mediatora.

38. Tak: M. Al-Kaber, Rynki finansowe, Państwowa Wyższa Szkoła Zawodowa w Suwałkach, Suwałki 2012, s. 9 , za: I. Pyka, Struktura i kierunki zmian rynku finansowego w procesach globalizacji, [w:] Rynek pieniężny i kapitałowy, [red.] I. Pyka, Katowice 2003, s. 12.

39. Tak: ibidem, s. 12.

40. J. Socha, Rynek. Giełda. Inwestycje, Olympus, Warszawa 1998, s. 11.

41. W. Dębski, Rynek finansowy i jego mechanizmy. Podstawy teorii i praktyki, PWN, Warszawa 2014, s. 17. Podobnie: A. Kaźmierczak, Pieniqdz i bank w kapitalizmie, Warszawa 1993.

42. Finanse, [red.] J. Ostaszewski, Difin, Warszawa 2013, s. 498. 
zakłady reasekuracji, spółdzielcze kasy oszczędnościowo-kredytowe i Krajową Spółdzielczą Kasę Oszczędnościowo-Kredytową, jak również pośredników kredytu hipotecznego oraz ich agentów ${ }^{43}$.

Spory pomiędzy wymienionymi wyżej podmiotami a ich klientami [tak osobami fizycznymi, jak i tzw. „ułomnymi osobami prawnymi” czy osobami prawnymi: zarówno konsumentami, jak i przedsiębiorcami] należy uznać za spory na rynku finansowym.

Przez pojęcie nadzoru nad rynkiem finansowym trzeba zaś rozumieć nadzór publiczny, który obejmuje nadzór: bankowy, nad rynkiem kapitałowym, ubezpieczeniowy, emerytalny, nad instytucjami płatniczymi, a także nad biurami usług płatniczych, instytucjami pieniądza elektronicznego, oddziałami instytucji zagranicznych pieniądza elektronicznego, nad agencjami ratingowymi, nad spółdzielczymi kasami oszczędnościowo-kredytowymi (a także Krajową Spółdzielczą Kasą Oszczędnościowo-Kredytowa]), jak również uzupełniający nadzór nad instytucjami kredytowymi, zakładami ubezpieczeń i reasekuracji oraz firmami inwestycyjnymi, które wchodzą w skład konglomeratu finansowego ${ }^{44}$.

Głównym celem nadzoru nad rynkiem finansowym jest zagwarantowanie działania rynku w sposób prawidłowy, zapewnienie jego bezpieczeństwa, stabilności oraz przejrzystości funkcjonowania. Ponadto nadzór ten służy budowaniu zaufania do rynku finansowego oraz zapewnieniu ochrony interesów uczestników rynku (m.in. poprzez rzetelną informację dotycząca jego funkcjonowania $)^{45}$.

Tak określony nadzór nad rynkiem finansowym sprawuje (po zmianach wprowadzonych ustawa z 2018 roku $^{46}$ ) Urząd Komisji Nadzoru Finansowego (UKNF) będący państwową osobą prawną 47. Istotnym zadaniem KNF w ramach nadzoru nad rynkiem finansowym jest, poza innymi działaniami, stwarzanie uczestnikom rynku finansowego możliwości polubownego rozwiązywania sporów. Odnosi się to do wcześniej określonych sporów, które - jak już wskazano - wynikają ze stosunków umownych, istniejacych pomiędzy podmiotami rynku finansowego, które podlegają nadzorowi KNF, a ich klientami. Jak wynika z danych zawartych w rocznych sprawozdaniach Sadu Polubownego $\mathrm{KNF}^{48}$, najwięcej wniosków o wszczęcie postępowania przez Sąd dotyczy sektora ubezpieczeniowego (w roku 2020 - 95,9\% spraw), sektora bankowego (w roku 2020 - 3,6\% spraw) oraz sektora kapitałowego (w roku 2020 - 0,05\% spraw). Przy czym na przestrzeni ostatnich lat w toku postępowań prowadzonych przed Sądem najczęściej podnoszonymi problemami były: odmowa lub częściowa odmowa wypłaty odszkodowania lub świadczenia z umowy ubezpieczenia (ponad 80\% przypadków), realizacja umowy ubezpieczenia, nieprawidłowa obsługa rachunku papierów

43. Por. informacje zawarte w: Sprawozdanie z działalności Urzędu Komisji Nadzoru Finansowego oraz Komisji Nadzoru Finansowego w 2019 roku, s. 10.

44. S. Peszkowski, System finansowania kosztów nadzoru nad rynkiem finansowym, CEDUR - KNF, Warszawa 2016, s. 4.

45. Ibidem.

46. Ustawa z dnia 9 listopada 2018 r. o zmianie niektórych ustaw w związku ze wzmocnieniem nadzoru nad rynkiem finansowym oraz ochrony inwestorów na tym rynku (Dz. U. 2018, poz. 2243).

47. Por. Ustawa z dnia 21 lipca 2006 r. o nadzorze nad rynkiem finansowym (tekst jedn. Dz. U. 2020, poz. 2059 z późn. zm.].

48. Por.: Sprawozdania z działalności Sądu Polubownego przy KNF w poszczególnych latach (2018-2020), https:// www.knf.gov.pl/dla_konsumenta/sad_polubowny/informacje_ogolne/sprawozdania?articleld=55606\&p_id=18 [dostęp: 10.12.2020] oraz: https://www.knf.gov.pl/dla__ynku/sad_polubowny_przy_KNF/informacje_ogolne/ sad_polubowny_rozwiazywanie_sporow_konsumenckich [dostęp: 30.06.2021]. 
wartościowych czy realizacja umowy kredytowej lub pożyczkowej ${ }^{49}$. Wydaje się, że powodami, dla których warto rozważać ustanowienie wyspecjalizowanej instytucji wspomagajacej na drodze polubownej rozwiązywanie przedmiotowych sporów są: złożoność spraw, a zatem także trudność w interpretacji przepisów regulujących dana problematykę; duża wartość przedmiotu sporu; jak również brak właściwej dla efektywnego rozwiązania sporu równowagi (tożsamej pozycji) pomiędzy jego uczestnikami.

Co zatem wpływa na fakt, że - w wyżej wymienionych kategoriach - sprawy, w których Centrum Mediacji Sądu Polubownego KNF wszczyna postępowania mediacyjne, kończą się w ok. 80\% zawarciem ugody?

\section{Centrum Mediacji Sądu Polubownego KNF}

Celem uzupełnienia odpowiedzi na postawione pytania badawcze i wstępnej eksploracji obranej tematyki zdecydowano się na realizację pilotażowych badań empirycznych z mediatorem - pracownikiem Sądu Polubownego KNF. Podczas realizacji badań o charakterze jakościowym posłużono się metodą studium przypadku (technika wywiadu, narzędzie scenariusz wywiadu ${ }^{50}$ ]. W dacie przeprowadzenia badania, jak również w chwili obecnej w Sądzie Polubownym KNF zatrudnionych było / jest 21 mediatorów ${ }^{51}$, przy czym dwóch z nich zostało na wniosek własny zawieszonych w czynnościach mediatora. W związku z powyższym zadecydowano, że pilotażowy wywiad pogłębiony (z planem kontynuowania i pogłębiania badań) zostanie zrealizowany z pracownikiem zatrudnionym w Sądzie Polubownym od początku jego istnienia (tj. od 2008 roku), który będzie miałjednocześnie dużą praktykę i skuteczność w zakresie postępowań mediacyjnych zakończonych ugodą oraz wyrazi zgodę na udział w badaniach. Wywiad zrealizowany został 3 sierpnia 2018 roku z mediatorem, który spełnił założone w pilotażu kryteria.

Respondent już na wstępie rozmowy podkreślił, że do Sądu Polubownego KNF trafiają przede wszystkim sprawy, w których jedną ze stron jest bank bądź firma ubezpieczeniowa, przy czym największą grupę stanowią klienci indywidualni. Powyższa prawidłowość ulega jednak powolnym zmianom, bowiem - jak zaznaczył rozmówca - pojawiają się także pojedyncze zapytania dotyczące mediacji za strony firm, które weszły w spór z bankiem. Ponadto wskazał, że w zależności od sektora rynku finansowego prowadzone sprawy w znaczącym stopniu różnią się od siebie. Podkreślił, że o ile postępowania, w których jedną ze stron stanowi bank, mają „typowo mediacyjny charakter" (przedstawiony w poprzedniej części niniejszego opracowania), o tyle postępowania, gdzie jedna ze stron jest ubezpieczyciel (których, jak wynika z prezentowanych statystyk jest prowadzona zdecydowana większośćc ${ }^{3}$ :

49. Zob. Sprawozdanie z działalności Sądu Polubownego przy KNF w zakresie pozasądowego rozwiązywania sporów konsumenckich w 2019 roku, https://www.knf.gov.pl/knf/pl/komponenty/img/SPRAWOZDANIE_Z\%20 DZIALALNOSCI_SADU_POLUBOWNEGO_PRZY_KNF_2019_70599.pdf [dostęp: 10.12.2020].

50. Scenariusz wywiadu składał się z 32 pytań pogrupowanych w trzy bloki tematyczne dotyczące 1. spraw rozpatrywanych w Sądzie Polubownym przy KNF, 2. efektywności i przyszłości Sądu Polubownego przy KNF 3. informacji na temat mediatorów.

51. Zgodnie z informacjami zawartymi na stronie: https://www.knf.gov.pl/dla_konsumenta/sad_polubowny/mediacja/lista-mediatorow?articleld=34152\&p_id=18 [dostęp: 10.12.2020].

52. Zob. przypis 50 i 51 . 
a) przypominają „przerzucanie się argumentami pomiędzy stronami”;

b) „są inicjowane przez ubezpieczyciela [...] z zamiarem: lepiej jednak załatwmy tę sprawę w drodze mediacji, ugody mediacyjnej, niż gdybyśmy mieli przegrać przed sądem, a może wtedy nawet przegralibyśmy jeszcze więcej”;

c) bywają prowadzone „w sposób zdalny, co już w samo w sobie trochę się kłóci z takim pełnym charakterem mediacji, bo tak naprawdę chodzi o to, żeby dwie strony się spotkały i mogły sobie w oczy spojrzeć. Telefonicznie to bardziej przypomina wymianę pism niż sama mediacja, chociaż jest to [...] rzeczywiście ułatwienie, szczególnie dla klientów, ale mam pewne wạtpliwości co do sensu tego rodzaju mediacji”. Powyższa wypowiedź miała zupełnie inny wydźwięk w czasie realizacji badań, bowiem wówczas mediacje w formie zdalnej należały do rzadkości i (jak wskazuje praktyka) nie stanowiły pożądanej formy.

Ponadto w wielu przypadkach sprawy, w których jedną ze stron jest ubezpieczyciel, stanowia większe wyzwanie dla mediatora, ponieważ nie zależą od sposobu prowadzenia postępowania i od umiejętności interpersonalnych oraz wiedzy w zakresie mediacji, a od kwoty wyliczonego przez lekarza orzecznika odszkodowania z tytułu ubezpieczenia.

Przywoływane już statystyki ${ }^{53}$, wskazujące na rokroczne zwiększanie wpływającej do instytucji liczby wniosków o przeprowadzenie mediacji oraz rosnąca liczba stron, które wyrażaja zgodę na udział w tej procedurze rozwiązania sporu, świadczą o wzrastającej roli Centrum Mediacji Sądu Polubownego KNF. Powyższą prawidłowość potwierdza także następująca wypowiedź badanego mediatora: „niektóre banki w umowach podpisywanych z klientami wpisują klauzulę o rozstrzyganiu sporów przed Sądem Polubownym KNF". Taki zapis stanowi w praktyce część wzorca umownego, którego zmiana jest praktycznie niemożliwa nawet w relacjach B2B. Respondent nie potrafił wprawdzie szczegółowo odpowiedzieć na pytanie, czy Sąd Polubowny KNF rozwiązuje spory, które w innych instytucjach zakończyły się niepowodzeniem, przy czym wskazał, że w swojej praktyce zawodowej zdarzyło mu się mediować w sprawie, w której poprzednie postępowanie mediacyjne nie doprowadziło do zawarcia ugody. Wydaje się zatem, że skierowanie sprawy do wyspecjalizowanej instytucji z prośbą o ponowną mediację (bez względu na efekt końcowy), może być spowodowane przeświadczeniem, że wyspecjalizowane centrum mediacyjne cechuje się większą efektywnością niż instytucja zajmująca się rozwiązaniem różnego rodzajów sporów (bez uwzględnienia specyfikacji spraw).

Innym elementem, który może świadczyć o skuteczności Centrum Mediacji Sądu Polubownego KNF, jest również powoływany wcześniej odsetek postępowań mediacyjnych zakończonych ugoda. Zgodnie ze sprawozdaniami z działalności Sądu Polubownego KNF ${ }^{54}$ odsetek sporów, w których przeprowadzono postępowanie mediacyjne i które zakończyły się zawarciem ugody, wynosi rokrocznie ok. $80 \%$, przy jednoczesnym 50\% wzroście liczby instytucji finansowych korzystających z usług Centrum. Powyższy trend został potwierdzony już w zrealizowanym pilotażu, bowiem $75 \%$ postępowań mediacyjnych prowadzonych przez badanego mediatora zostało zakończonych ugoda. Ponadto respondent uznał, że działalność Centrum Mediacji Sądu Polubownego KNF można określić mianem skutecznego.

Ważnym elementem mającym znaczący wpływ na istotną rolę Centrum Mediacji Sądu Polubownego KNF w rozwiązywaniu sporów pozasądowych (na rynku usług finansowych) jest

53. Zob. przypisy $16-18$.

54. Ibidem. 
krótki czas trwania postępowań mediacyjnych. Jak wskazywał respondent „w większości wypadków sprawy udaje się zakończyć na jednym posiedzeniu. To jest tylko kwestia uzgodnienia terminu. Ja staram się, żeby termin uzgodnić nie później niż w ciągu miesiąca od złożenia wniosku. Czasem udaje się nawet jeszcze krócej. Przedłużenie wynika najczęściej sytuacji obiektywnych: urlop, choroba [...]. W kilku przypadkach potrzebne było drugie posiedzenie mediacyjne [...]. Najdłuższe z tych postępowań trwało 3-4 miesiące".

Respondent jednoznacznie wypowiedział się także o konieczności prowadzenia mediacji na rynkach finansowych, które w jego przekonaniu są nie tylko bardzo przydatne i pozwalające szybko oraz sprawnie doprowadzić do ugody, ale także (a być może przede wszystkim), ze względu na zawężenie obszaru działania mediacyjnego pozwalają zrozumieć obu stronom istotę sporu, odpowiedzieć na pojawiające się w toku postępowania pytania, co w konsekwencji prowadzi do rozwiązania sporu w sposób zadowalający obie strony. Na uwagę zasługuje także wypowiedź badanego świadczaca, że Sąd Polubowny KNF stanowi, w jego przekonaniu, doskonałą alternatywę dla innych instytucji rozstrzygających spory, np. arbitra bankowego przy Związku Banków Polskich. W tym miejscu należy wskazać, że Sąd Polubowny przy KNF jest stałym i niezależnym sądem polubownym, który rozpatruje spory między uczestnikami rynku finansowego (w tym podmiotami świadczącymi usługi i ich odbiorcami - tak konsumentami, jak i innymi podmiotami], poprzez wybór jednej z dwóch ścieżek rozwiązania sporu: mediacji lub arbitrażu. Celem pierwszej procedury - poufnej, dobrowolnej i odformalizowanej - jest zawarcie ugody pomiędzy stronami sporu przy udziale mediatora. Idea poufnego, dobrowolnego, ale sformalizowanego postępowania arbitrażowego jest zaś rozstrzygnięcie sporu w drodze wyroku Sądu Polubownego. Przy czym przed Sądem Polubownym przy KNF rozpatrywane są sprawy, których wartość przedmiotu sporu, co do zasady, wynosi co najmniej 500 zł, oraz sprawy o prawa niemajątkowe. Arbiter Bankowy przy ZBP jest z kolei instytucją, która rozstrzyga spór na zasadach postępowania arbitrażowego (zawsze wiążącego bank) w prowadzonym (dobrowolnym dla konsumenta, a obligatoryjnym dla podmiotu] postępowaniu, którego przedmiotem jest spór powstały wyłącznie pomiędzy konsumentem a bankiem - członkiem Związku Banków Polskich albo bankiem niezrzeszonym, który dobrowolnie poddał się orzecznictwu Arbitra Bankowego. W przypadku wszczęcia procedury przed Arbitrem Bankowym wartość przedmiotu sporu nie może być wyższa niż kwota 12 000,00 zł, a dla sporów dotyczących kredytów hipotecznych - nie może przekraczać kwoty 20 000,00 zł, wnioskodawca zaś wyczerpał procedurę postępowania reklamacyjnego w banku. Ważny jest również fakt, że rozstrzygany przez Arbitra Bankowego spór dotyczy roszczeń pieniężnych z tytułu niewykonania lub nienależytego wykonania przez bank czynności bankowych lub innych czynności na rzecz konsumenta ${ }^{55}$.

We wprowadzeniu zwrócono uwagę, że jednym z celów niniejszego artykułu jest wskazanie zasadności prowadzenia postępowań mediacyjnych w sporach na rynkach finansowych. W związku z powyższym istotne było poznanie opinii respondenta dotyczącej przyszłości Sąu Polubownego KNF. Mediator zaznaczył, że pomimo iż Centrum Mediacji Sądu Polubownego KNF stanowi jedną z niewielu (jeżeli nie jedyna) ${ }^{56}$ możliwość prowadzenia postępowań mediacyjnych

55. Szerzej na temat instytucji Arbitra Bankowego przy ZBP zob. np. https://zbp.pl/dla-klientow/arbiter-bankowy [dostęp: 15.08.2021].

56. Stan na sierpień $2018 \mathrm{r}$. 
w sporach z podmiotami rynku finansowego, to jednak w jego przekonaniu uregulowania wymagają następujące kwestie:

a) ograniczenie tzw. „mediacji zdalnych”, np. prowadzonych w formie telekonferencji;

b) rozważenie wprowadzenia tzw. mechanizmu koncyliacyjnego, który umożliwiałby zaproponowanie przez mediatora sposobu, w jaki spór mógłby zostać rozstrzygnięty (działanie pośrednie między arbitrażem a mediacja].

Odpowiedzią na drugą z potrzeb zgłaszanych przez respondenta, która jednocześnie potwierdza koniczność powstawania i rozwoju wyspecjalizowanych centrów mediacyjnych, było stworzenie w 2016 roku podstaw prawnych funkcjonowania systemu pozasądowego rozwiązywania sporów, w postaci przepisów u.p.r.s.k. W ramach tak określonego prawnie systemu działają wyspecjalizowane podmioty niepubliczne i publiczne, które zajmuja się rozwiązywaniem sporów typowych dla danego sektora gospodarki. Niepublicznymi podmiotami sektorowymi są instytucje tworzone przez przedsiębiorców z danej branży (np. Arbiter Bankowy, podmiot utworzony przez Związek Banków Polskich] ${ }^{57}$. Wśród już powstałych publicznych podmiotów sektorowych wyróżnić można: a) powoływany w niniejszym opracowaniu Sąd Polubowny przy KNF, zajmujący się sporami pomiędzy usługodawcami rynku finansowego a ich odbiorcami, w tym konsumentami;

b) Rzecznika Finansowego, zajmującego się sporami pomiędzy klientami a podmiotami rynku finansowego;

c) Prezesa Urzędu Komunikacji Elektronicznej, zajmującego się sporami pomiędzy konsumentami a dostawcami publicznych usług telekomunikacyjnych oraz pomiędzy nadawcami albo adresatami a operatorami pocztowymi;

d) Koordynatora do spraw negocjacji działającego przy Prezesie Urzędu Regulacji Energetyki, zajmującego się rozwiązywaniem sporów z branży energetycznej pomiędzy konsumentami lub prosumentami będącymi konsumentami a przedsiębiorstwami energetycznymi;

e) Rzecznika Praw Pasażera Kolei, działającego przy Prezesie Urzędu Transportu Kolejowego, zajmującego się rozwiązywaniem sporów z branży transportu kolejowego pomiędzy pasażerem a sprzedawcą biletów, operatorem turystycznym, przewoźnikiem kolejowym, zarządcą infrastruktury kolejowej, właścicielem dworca bądź zarządzającym dworcem ${ }^{58}$.

Poza niepublicznymi i publicznymi podmiotami sektorowymi świadczącymi usługi w zakresie pozasądowego rozwiązywania określonych kategorii sporów, przepisy u.p.r.s.k. pozwoliły również na stworzenie podmiotu o charakterze horyzontalnym - Inspekcji Handlowej, która jest właściwa do rozwiązywania sporów konsumenckich, w przypadku braku utworzenia podmiotu sektorowe$\mathrm{go}^{59}$. Co więcej, w ramach tak skonstruowanego systemu przepisy u.p.r.s.k. pozwalają na tworzenie nowych wyspecjalizowanych centrów zajmujaccych się pozasądowym rozwiązywaniem sporów.

Ponownego podkreślenia wymaga również fakt, że w ramach prowadzonych postępowań przepisy art. 3 u.p.r.s.k. przewidują możliwość zbliżenia stanowisk stron w celu rozwiązania przez nie sporu, przedstawienia stronom propozycji rozwiązania sporu, a także rozstrzygnięcia sporu i narzucenia stronom jego rozwiazania. Oznacza to de facto wprowadzenie mechanizmów koncyliacyjnych do postępowań prowadzonych w oparciu o przepisy ustawy.

57. Por. informacje przedstawione na stronie internetowej Urzędu Ochrony Konkurencji i Konsumentów dostępnej pod adresem: http://polubowne.uokik.gov.pl/instytucje,4,pl.html [10.12.2020 r.].

58. Ibidem.

59. Ibidem. 


\section{Podsumowanie}

Zarówno analiza powołanych danych statystycznych KNF, Sądu Polubownego KNF i Ministerstwa Sprawiedliwości, zebranych w sądach powszechnych w zakresie prowadzonych postępowań mediacyjnych, jak również przeprowadzone badanie jakościowe wzmacniają tezę autorów o efektywności wyspecjalizowanych centrów mediacyjnych w Polsce, czego przykładem może być działalność Centrum Mediacji Sądu Polubownego przy KNF. Autorzy zdają sobie jednak sprawę, że kompletna weryfikacja tej tezy wymaga prowadzenia dalszych badań, chociażby w zakresie porównania przykładowego Centrum Mediacji z innymi tego typu centrami. Przeprowadzona analiza pozwala jednak na sformułowanie wniosku, że chociażby ze względu na wysoką (80\%) skuteczność prowadzonych postępowań mediacyjnych istnienie wyspecjalizowanych centrów mediacji i ich dalszy rozwój, także w ramach systemu pozasądowego rozwiązywania sporów, jest potrzebne. Przykład Centrum Mediacji Sądu Polubownego KNF potwierdza istotną rolę przedmiotowych jednostek w przyczynianiu się do skutecznego rozwiązywania określonych kategorii sporów na drodze pozasądowej. Podkreślaja to również przepisy u.p.r.s.k. dające podstawę prawną do funkcjonowania wyspecjalizowanych centrów mediacji w ramach pozasądowego systemu rozwiązywania sporów. Wydaje się, że w chwili obecnej ich rola jest uzupełnienie i wsparcie rozwiązywania sporów w ramach mediacji sądowych. Niewykluczone jednak, że ze względu na wysoką efektywność (jak pokazuje przykład Centrum Mediacji Sądu Polubownego KNF] - m.in.: relatywnie szybki czas procedowania, niewielki koszt po stronie stron biorących w nim udział, prowadzenie przez wyspecjalizowanego mediatora, wysoki odsetek zawieranych ugód - ich rolą w niedalekiej przyszłości będzie zastapienie nie tylko sądowych postępowań mediacyjnych w pewnych określonych kategoriach spraw cywilnych i gospodarczych, ale również obniżenie do niezbędnego minimum liczby spraw kierowanych do postępowań sądowych.

\section{Wykaz źródeł}

\section{Literatura:}

Dębski W., Rynek finansowy i jego mechanizmy. Podstawy teorii i praktyki, PWN, Warszawa 2014. Finanse, Ostaszewski J. [red.], Difin, Warszawa 2013.

Gmurzyńska E., [w:] Mediacje, Teoria i praktyka, Gmurzyńska E., Morek R. [red.], Wolters Kluwer, Warszawa 2009.

Gmurzyńska E., [w:] Mediacja, Mazowiecka L. [red.], Wolters Kluwer, Warszawa 2009.

Kalisz A., Zienkiewicz A., Mediacja sqdowa i pozasqdowa. Zarys wykładu, Wolters Kluwer, Warszawa 2014.

Kaźmierczak A., Pieniqqdz i bank w kapitalizmie, PWN, Warszawa 1993.

Kopaliński W., Słownik wyrazów obcych i zwrotów obcojęzycznych z almanachem, PWN, Warszawa 2000.

Malczyk M., [w:] Kodeks postępowania cywilnego. Tom I. Komentarz. Art. 1-729, GóraBłaszczykowska A. [red.], Warszawa 2016.

Nowak P., Kornacka B., Mediacja i inne polubowne formy rozwiqzywania sporów na rynku finansowym, KNF, Warszawa 2016.

Peszkowski, System finansowania kosztów nadzoru nad rynkiem finansowym, KNF, Warszawa 2016. 
Peters D., An introduction to mediation theory and skills, University of Florida, Gainesville FL 2006. Pieckowski S., Mediacja gospodarcza, Difin, Warszawa 2015.

Pyka I., Struktura i kierunki zmian rynku finansowego w procesach globalizacji, Rynek pieniężny i kapitałowy, Pyka I. [red.], Wydawnictwo Akademii Ekonomicznej, Katowice 2003.

Sitt A., Mediating commercial disputes, Canada Law Book Inc., Aurora 2003.

Socha J., Rynek. Giełda. Inwestycje, OLYMPUS, Warszawa 1998.

Stefańska E., [w:] Kodeks postępowania cywilnego. Komentarz. Tom I. Art. 1-505 ${ }^{38}$, Manowska M. [red.], Wolters Kluwer, Warszawa 2015.

\section{Źródła internetowe:}

Centra Arbitrażu i Mediacji: https://www.cammediacje.pl/assets/files/raport-cam-final.pdf [dostęp: 10.11.2020].

Centrum Mediacji Sądu Polubownego KN: https://www.knf.gov.pl/knf/pl/komponenty/img/0_mediacji_-slajdy\%202019_65959.pdf [dostęp: 10.12.2020].

KNF nagradza ubezpieczycieli za mediację, „Rzeczpospolita” 31.03.2016, http://www.rp.pl/ Ubezpieczenia/303319899-KNF-nagradza-ubezpieczycieli-za-mediacje.html\#ap-1 [dostęp: 13.11.2020].

Mobbing akademicki - mediator akademicki, http://nfamob.wordpress.com/2009/11/05/projekt-roboczy-ustawy-o-mediatorach-i-zasadach-prowadzenia-mediacji/ [dostęp: 10.11.2020].

Raport pt. Diagnoza stanu stosowania mediacji oraz przyczyn zbyt niskiej w stosunku do oczekiwanej popularności mediacji, http://mediacja.gov.pl/Badania-analizy-i-statystyki-.html [dostęp: 10.11.2020].

Rejestr podmiotów uprawnionych do prowadzenia postępowań w ramach pozasądowego rozwiązywania sporów, http://polubowne.uokik.gov.pl/rejestr,5,pl.html [dostęp: 10.11.2020].

Roboczy projekt ustawy o mediatorach i zasadach prowadzenia mediacji w sprawach skierowanych przez organa procesowe, http://www.mediacje.lex.pl/czytaj/-/artykul/spoleczna-rada-o-projekcie-ustawy-o-mediatorach [dostęp: 10.11.2020]; http://www.lex.pl/czytaj/-/artykul/ ms-pracuje-nad-nowymi-przepisami-o-mediacji [dostęp: 10.11.2020].

Sprawozdanie z działalności Komisji Nadzoru Finansowego w roku 2016, https://www.knf.gov. $\mathrm{pl} / \mathrm{knf} / \mathrm{pl} / \mathrm{komponenty} / \mathrm{img} / 1$ OST_PRZYJETY_28_03_na\%2OKNF_28_03_Sprawozdanie_2016.pdf [dostęp: 10.12.2020].

Sprawozdanie z działalności Urzędu Komisji Nadzoru Finansowego oraz Komisji Nadzoru Finansowego w 2018 roku, https://www.knf.gov.pl/knf/pl/komponenty/img/Sprawozdanie\%20z\%20działalności\%20UKNF\%20oraz\%20KNF\%20w\%202018\%20roku_66979.pdf [dostęp: 10.12.2020].

Sprawozdanie z działalności Urzędu Komisji Nadzoru Finansowego oraz Komisji Nadzoru Finansowego w 2019 roku, https://www.knf.gov.pl/knf/pl/komponenty/img/Sprawozdanie\%202019.pdf [dostęp: 10.12.2020].

Sprawozdania z działalności Sąu Polubownego przy KNF w poszczególnych latach (20182009), https://www.knf.gov.pl/dla_konsumenta/sad_polubowny/informacje_ogolne/ sprawozdania? articleld=55606\&p_id=18 [dostęp: 10.12.2020].

Sprawozdanie z działalności Sądu Polubownego przy KNF w zakresie pozasądowego rozwiązywania sporów konsumenckich w 2019 roku, https://www.knf.gov.pl/knf/pl/komponenty/img/SPRAWOZDANIE_Z\%20 DZIALALNOSCI_SADU_POLUBOWNEGO_PRZY_KNF_2019_?0599.pdf [dostęp: 10.12.2020]. 
Urząd Ochrony Konkurencji i Konsumentów, http://polubowne.uokik.gov.pl/instytucje,4,pl.html [dostęp: 10.12.20202].

Założenia ogólne propozycji działań zmierzajacych do pełniejszego wykorzystania potencjału mediacji jako skutecznej metody rozwiqzywania sporów i konfliktów, http://ms.gov.pl/pl/ dzialalnosc/mediacje/spoleczna-rada-ds-alternatywnych-metod-rozwiazywania-konfliktow-i-sporow/dokumenty-deklaracje/ [dostęp: 10.11.2020].

https://www.gov.pl/web/sprawiedliwosc/dane-statystyczne-dotyczace-mediacji [dostęp: 10.11.2020].

https://www.knf.gov.pl/knf/pl/komponenty/img/SP\%20przy\%20KNF\%20-\%20o\%20mediacji_6745?. pdf [dostęp: 10.11.2020].

https://www.knf.gov.pl/dla_konsumenta/sad_polubowny/mediacja/lista-mediatorow? articleld=34152\&p_id=18 [dostęp: 10.12.2020].

\section{About the need for specialized mediation centers in Poland - example of the Mediation Center of the Arbitration Court at the Polish Financial Supervision Authority}

The purpose of this article is to briefly present the essence of mediation and the specifics of disputes occurring on financial markets. The indicated discussion is to be used, among others, by analysis of mediation proceedings conducted on financial markets, based on pilot empirical studies (using the case study method) conducted at the Arbitration Center of the Polish Financial Supervision Authority, and determining the role of specialized mediation centers in the development of out-of-court mediation in Poland. The authors argue that specialized mediation centers dealing with mediation proceedings only in a strictly defined category of civil and commercial cases show high efficiency, therefore they can support court proceedings or replace them in this regard. Therefore, specialized centers should be supported by appropriate legal regulations that would allow for their development, constituting an alternative to general centers dealing with mediation proceedings in all possible categories of cases suitable for mediation.

Key words: ADR, mediation, amicable settlements, mediation center, Polish Financial Supervision Authority.

DR MARTA J. SKRODZKA - Wydział Nauk Społecznych i Humanistycznych Państwowej Wyższej Szkoły Informatyki i Przedsiębiorczości w Łomży, Katedra Nauk Prawnych

ORCID: 0000-0001-5995-1394

e-mail: mjskrodzka@pwsip.edu.pl,skrodzkam@life.pl

DR ANNA SZAFRANEK - Wydział Nauk Społecznych i Humanistycznych Państwowej Wyższej Szkoły Informatyki i Przedsiębiorczości w Łomży, Katedra Nauk Prawnych

ORCID: 0000-0002-3902-0063

e-mail: aszafranek@pwsip.edu.pl 